\title{
Plasma Vasopressin, Renin, and Catecholamines during Nitroprusside-Induced Maternal and Fetal Hypotension in Sheep
}

\author{
ALAN B. ZUBROW, SALHA S. DANIEL, RAYMOND I. STARK, M. KAZIM HUSAIN, AND \\ L. STANLEY JAMES \\ Departments of Pediatrics and Anesthesiology, College of Physicians and Surgeons, Columbia University, \\ Harlem Hospital, Babies Hospital, New York, New York 10032
}

\begin{abstract}
The release of vasopressin, renin, and catecholamines by the fetus during either maternal or fetal hypotension was examined in chronically catheterized fetal lambs. Nitroprusside was infused intravenously for $1 \mathrm{~h}$ into seven pregnant ewes (maternal hypotension) or nine fetal lambs (fetal hypotension); the rates were adjusted to achieve a 15 to $30 \%$ decrease in mean blood pressure. During maternal hypotension, mean $\pm \mathrm{SE}$ vasopressin in maternal plasma increased from $1.2 \pm 0.2 \mathrm{pg} \cdot \mathrm{ml}^{-1}$ to 208 $\pm 153 \mathrm{pg} \cdot \mathrm{ml}^{-1}$ and plasma renin activity increased from $1.5 \pm 0.3 \mathrm{ng} \cdot \mathrm{ml}^{-1} \cdot \mathrm{h}^{-1}$ to $6.6 \pm 1.6 \mathrm{ng} \cdot \mathrm{ml}^{-1} \cdot \mathrm{h}^{-1}$. Fetal vasopressin and plasma renin activity also increased during the same interval from $1.1 \pm 0.3$ to $16.9 \pm 7.5 \mathrm{pg} \cdot \mathrm{ml}^{-1}$ and $3.7 \pm 1.1$ to $10.5 \pm 2.85 \mathrm{ng} \cdot \mathrm{ml}^{-1} \cdot \mathrm{h}^{-1}$, respectively; but no changes were observed in fetal blood pressure, heart rate, or acid base status. During fetal hypotension, mean vasopressin in fetal plasma increased from $4.3 \pm 3.4 \mathrm{pg}$. $\mathrm{ml}^{-1}$ to $1054 \pm 772 \mathrm{pg} \cdot \mathrm{ml}^{-1}$, plasma renin activity increased from $5.7 \pm 2.2 \mathrm{ng} \cdot \mathrm{ml}^{-1}$ to $22.2 \pm 7.1 \mathrm{ng} \cdot \mathrm{ml}^{-1} \cdot \mathrm{h}^{-1}$, and total catecholamines from $174 \pm 58 \mathrm{pg} \cdot \mathrm{ml}^{-1}$ to $810 \pm$ $416 \mathrm{pg} \cdot \mathrm{ml}^{-1}$. There was no change in fetal heart rate, acid base status, osmolality, or sodium concentration. The fetus became and remained hypertensive for at least $1 \mathrm{~h}$ after the end of infusion. This prolonged hypertension was associated with elevated levels of vasopressin and plasma renin activity. Peak vasopressin levels were proportional to the total nitroprusside dose in both the ewe and fetus (maternal $r=0.796$, fetus $r=0.870$ ). These experiments indicate that as in the adult, vasopressin and the reninangiotensin system in the fetus are stimulated by euvolemic hypotension and may play an important role in the maintenance of fetal blood pressure during an hypotensive challenge. We speculate that the prolonged rebound hypertension represents immaturity of the fetus to fine tune the regulation, release, or metabolism of vasoactive mediators. More likely, the hypertension and elevated hormone levels represent homeostatic mechanisms to combat the nitroprusside-induced diminished cardiac output. Lastly, fetal release of vasopressin, renin-angiotensin, and norepinephrine during maternal hypotension suggests that they are sensitive indicators of early fetal compromise. (Pediatr Res 24: 73-78, 1988)
\end{abstract}

Received October 6, 1986; accepted March 3, 1988.

Correspondence and reprints Alan B. Zubrow, M.D., The Medical College of Pennsylvania, 3300 Henry Avenue, Philadelphia, PA 19129.

Supported in part by Grants 5RO1 HD 12737 and HL 14218 from the National Institute of Health.
The fetus may be compromised by episodes of maternal hypotension (postural changes, regional anesthesia, placenta previa, etc.) or fetal hypotension (cord occlusion, fetal blood loss secondary to abruptio placentae, etc.) (1). In adults of several species, hypotension is known to stimulate several vasoactive systems which act to restore blood pressure towards normal values (2-8). The ability of the fetus to similarly withstand hypotension may have a significant influence on subsequent short-term and longterm outcome. The present studies were undertaken to determine the fetal response to both maternal and fetal hypotension with respect to fetal release of vasopressin, renin, and catecholamines in the maintenance of fetal blood pressure, heart rate, and arterial acid-base status.

\section{MATERIALS AND METHODS}

Surgery. Sixteen healthy mixed bred pregnant ewes, 2-4 yr old, and their fetuses, were catheterized at 110-125 days gestation. Surgery was performed under spinal anesthesia, supplemented with pentobarbital as described previously (9). The maternal femoral artery and vein. were isolated and catheterized with no. 8 French feeding tubes (Argyle, St. Louis, MO) which were then advanced into the abdominal aorta. After abdominal incision and exposure of the uterus, the fetal neck was isolated and the carotid artery and jugular vein were catheterized with no. 5 French feeding tubes. The fetal skin, uterus, and maternal peritoneum were closed. Maternal fetal catheters were tunneled subcutaneously and brought out via a small stab wound in the maternal flank. At least $1 \mathrm{wk}$ was allowed for recovery from the surgery before experimentation was begun. Surgery was performed at a mean gestational age of $128 \pm 2.6$ days.

Study. The animals were randomly divided into two experimental groups: group A, maternal hypotension (seven animals) and group B, fetal hypotension (nine animals). After a 30-min control period of stable blood pressure and heart rate measurements, freshly prepared sodium nitroprusside (Nipride, Hoffman LaRoche, Inc., Nutley, NJ) $\left(0.33 \mathrm{mg} \cdot \mathrm{ml}^{-1}\right.$ normal saline solution) was infused intravenously into the mother (group A) or the fetus (group B). The rate of infusion was adjusted to maintain a mean arterial blood pressure 15 to $30 \%$ below control levels in both groups. The range of total dose of nitroprusside administered was 7.8-140.2 mg for maternal hypotension and 1.34$18.26 \mathrm{mg}$ (about $2.5 \pm 1.75 \mathrm{mg} \cdot \mathrm{kg}^{-1}$ ) for fetal hypotension. The experimental period, which lasted $60 \mathrm{~min}$, was followed by an additional hour of monitoring.

Arterial blood pressure was measured continuously using a Statham transducer (23 Db); by using amniotic fluid pressure as a reference corrections were made for extraneous factors (such as change in maternal posture) that might effect blood pressure 
measurement. Heart rate was determined by a cardiotachometer triggered by pulse pressure. Measurements were recorded on a multichannel Beckman polygraph. Arterial blood samples were taken before ( $0 \mathrm{~min}$ ), during ( 30 and $60 \mathrm{~min})$, and after ( $90 \mathrm{~min}$ ) the nitroprusside infusion. The total amount of blood withdrawn per study was $20 \mathrm{ml}$ from the mother and $16 \mathrm{ml}$ (about $10 \mathrm{ml}$. $\mathrm{kg}^{-1}$ ) from the fetus. Blood samples for assay of vasopressin and renin were collected in chilled EDTA tubes, catecholamine determination in chilled EGTA tubes, containing glutathione, and for blood gases, sodium, and osmolality determination in a heparinized syringe. Each sample was replaced with an equivalent amount of normal saline solution. The volume of blood withdrawn over the 2 -h period of these experiments has been shown not to affect vasopressin levels (10).

Biochemical analysis. The plasma was separated at $4^{\circ} \mathrm{C}$ by centrifugation at $2000 \times \mathrm{g} 15 \mathrm{~min}$ and was stored at $-30^{\circ} \mathrm{C}$ for later determination of plasma renin activity, catecholamines, vasopressin, electrolytes, and osmolality. Blood $\mathrm{pH}$ and gas tensions were measured immediately using microelectrodes and a Radiometer blood gas monitor.

Renin activity was measured by generation of angiotensin I using New England Nuclear Rianen angiotensin I[ $\left[{ }^{125} \mathrm{I}\right]$ radioimmunoassay kit (New England Nuclear, Boston, MA), whose sensitivity is approximately $2 \mathrm{pg} / \mathrm{sample}$ with a precision of 0.55 \pm 0.11 for values less than $2 \mathrm{ng} \cdot \mathrm{ml}^{-1} \cdot \mathrm{h}^{-1}$ and $7.40 \pm 0.81$ for values $7-10 \mathrm{ng} \cdot \mathrm{ml}^{-1} \cdot \mathrm{h}^{-1}$. Epinephrine and norepinephrine were measured by a radioenzymatic method, using Upjohn's Cat-AKit. Sensitivity of Upjohn's method ranges from $2-5 \mathrm{pg} / 50 \mu \mathrm{l}$ for both epinephrine and norepinephrine. The average coefficient of variation within standard runs was $10 \%$ for epinephrine and $7.5 \%$ for norepinephrine. Vasopressin was analyzed by radioimmunoassay (11); the assay can detect $0.2 \mathrm{pg}$ vasopressin/ sample. Interassay variation was $17 \%$ and intraassay variation $8 \%$.

Plasma sodium concentration and osmolality were measured using an Instrumentation Lab Flame Photometer and an Advanced Instrument Hi-Precision Research Osmometer. The coefficients of variation of the methods of determination of sodium concentration and osmolality were \pm 1 and $\pm 2 \%$, respectively.

Statistical analysis. All data are expressed as mean \pm SE. Two animals in group A required increasing sodium nitroprusside infusion rates to maintain hypotension; they seemed to develop tachyphylaxis in response to the nitroprusside infusion. One of these experiments was stopped after $35 \mathrm{~min}$ to prevent possible cyanide toxicity, a side effect of nitroprusside. Because there was no statistical difference when the data from group A were analyzed with and without inclusion of this animal, the data presented include all seven studies; the 35 -min sample data are included with the end of the experimental period data $(60 \mathrm{~min})$ for the other animals. All data were analyzed using a two-tailed paired $t$ test. The vasoactive mediator data were transformed using a log function to decrease the influence of variance between the animals. All $p$ values listed for vasopressin, renin activity, and catecholamines represent analysis using the log transformation. Not all measurements were made on all animals due to technical problems; however each mean represents measurements on no less than five samples.

\section{RESULTS}

Group A-maternal hypotension. Nitroprusside infusion into the ewe lowered mean blood pressure by $15-20 \%(12-20 \mathrm{~mm}$ $\mathrm{Hg})$ to values significantly lower than control $(p<0.01)$ during the experimental period (Fig. 1). When the nitroprusside was discontinued blood pressure returned to preinfusion values within $2 \mathrm{~min}$. Maternal heart rate remained statistically unchanged except at the beginning and immediately after cessation of the infusion, when it increased $(p<0.05)$. Fetal blood pressure and heart rate remained unchanged during and after infusion of nitroprusside into the mother. In only one animal was there a
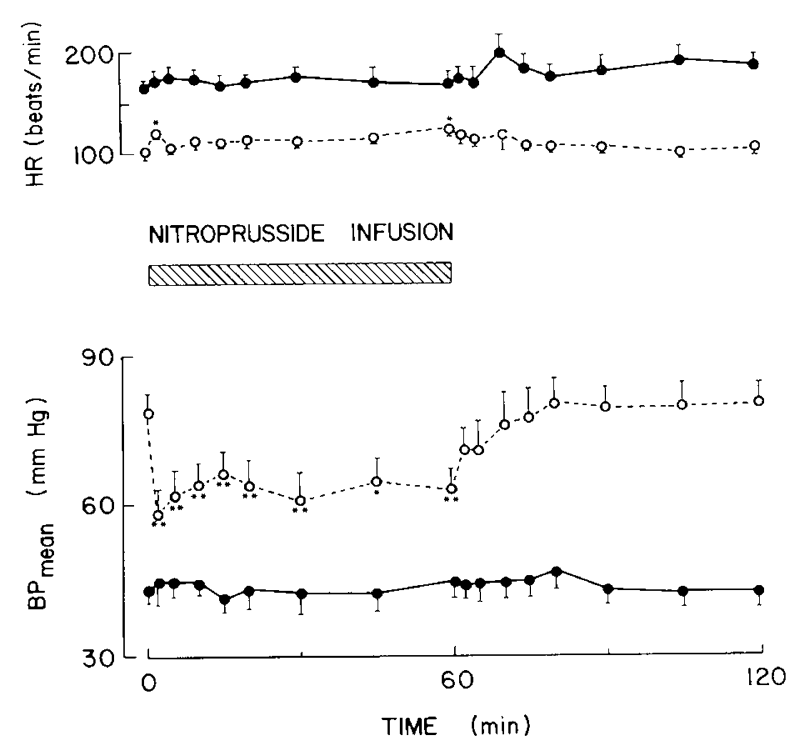

Fig. 1. Changes in heart rate (top) and mean blood pressure (bottom) before, during, and after maternal nitroprusside-induced hypotension (as indicated). The solid line represents changes in the fetus and the broken line represents changes in the mother. Data expressed as mean $\pm \mathrm{SE} .{ }^{*} p$ $<0.05,{ }^{* *} p<0.01$.

significant correlation between maternal and fetal blood pressures during the infusion. The vasoactive mediator response to maternal hypotension is displayed in Figure 2. Maternal vasopressin concentration increased from $1.2 \pm 0.2 \mathrm{pg} \cdot \mathrm{ml}^{-1}$ to 208 $\pm 153 \mathrm{pg} \cdot \mathrm{ml}^{-1}(p<0.0001)$ after $60 \mathrm{~min}$ of maternal hypotension. Peak maternal vasopressin levels significantly correlated with the total nitroprusside dose $(r=0.796, p<0.05)$. Fetal vasopressin concentration also increased over the same interval from $1.1 \pm 0.3 \mathrm{pg} \cdot \mathrm{ml}^{-1}$ to $16.9 \pm 7.5 \mathrm{pg} \cdot \mathrm{ml}^{-1}(p<0.004)$. Maternal plasma renin activity increased from a control value of $1.5 \pm 0.3$ to $6.6 \pm 1.6 \mathrm{ng} \cdot \mathrm{ml}^{-1} \cdot \mathrm{h}^{-1}(p<0.005)$. The rise in fetal plasma renin activity during the same period was from $3.7 \pm 1.1$ to $10.5 \pm 4.3 \mathrm{ng} \cdot \mathrm{ml}^{-1} \cdot \mathrm{h}^{-1}(p<0.05)$. Maternal total catecholamine concentrations increased from $251 \pm 15$ to $724 \pm 179 \mathrm{pg}$. $\mathrm{ml}^{-1}(p<0.05)$ after $60 \mathrm{~min}$ of hypotension. Similarly, fetal total catecholamine levels increased during this same period from $351 \pm 35$ to $1206 \mathrm{pg} \cdot \mathrm{ml}^{-1}(p<0.01)$.

The ewe that developed tachyphylaxis and required discontinuation of the nitroprusside after $35 \mathrm{~min}$ had an increase of vasopressin from 0.5 to $1120 \mathrm{pg} \cdot \mathrm{ml}^{-1}$; renin activity increased from 1.1 to $5.8 \mathrm{ng} \cdot \mathrm{ml}^{-1} \cdot \mathrm{h}^{-1}$, epinephrine from 91 to 454 and norepinephrine from 132 to $782 \mathrm{pg} \cdot \mathrm{ml}^{-1}$.

There were no statistically significant changes in the mean acid base status or blood gas tensions of the mother or fetus at any time interval (Table 1). The mean control plasma sodium concentration $\left(\right.$ maternal $=146 \pm 1.2 \mathrm{mEq} \cdot 1^{-1}$ and fetal $=143$ $\pm 2.0 \mathrm{mEq} \cdot 1^{-1}$ ) and osmolality (maternal $=300 \pm 3.3 \mathrm{mosmol}$. $\mathrm{kg}^{-1}$ and fetal $=297 \pm 4.7 \mathrm{mosmol} \cdot \mathrm{kg}^{-1}$ ) were within normal range for sheep and remained unchanged throughout this experiment. The hematocrit also was unchanged (maternal: start = $29.9 \pm 1.0 \%$, end $=28.8 \pm 1.4 \%$ and fetal: start $=34.2 \pm 1.1 \%$, end $=34.4 \pm 1.1 \%$ ).

Group B-fetal hypotension. Infusion of nitroprusside to the fetus significantly lowered mean blood pressure by $15-30 \%$ (Fig. 3) $(p<0.01)$. Within 2 to $5 \mathrm{~min}$ after discontinuation of the infusion, blood pressure rose above control value and the animals became significantly hypertensive $(p<0.05)$ for the remainder of the postinfusion observation period $(1 \mathrm{~h})$. The fetal heart rate remained unchanged during and after the infusion.

The vasoactive mediator response to fetal hypotension is displayed in Figure 4. Vasopressin concentration increased from 


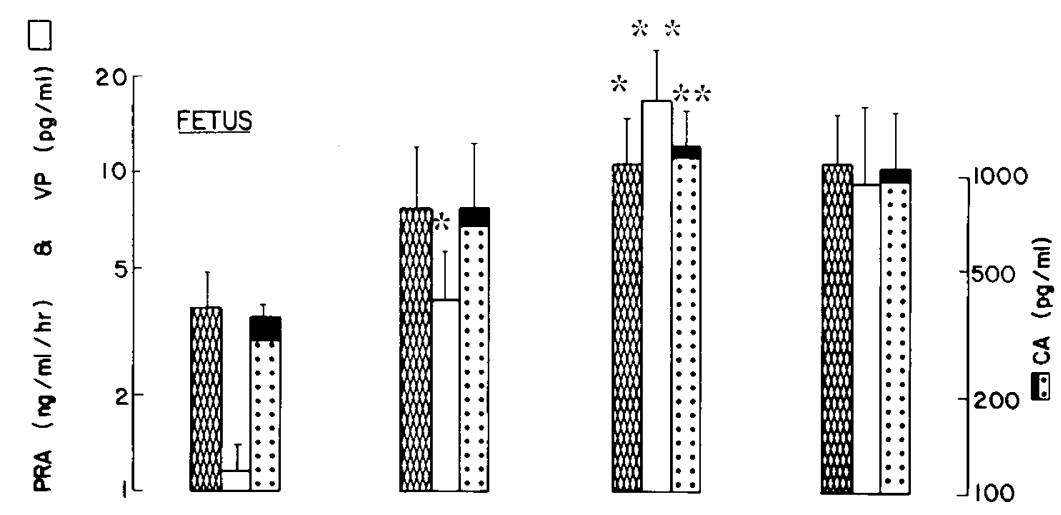

NITROPRUSSIDE INFUSION

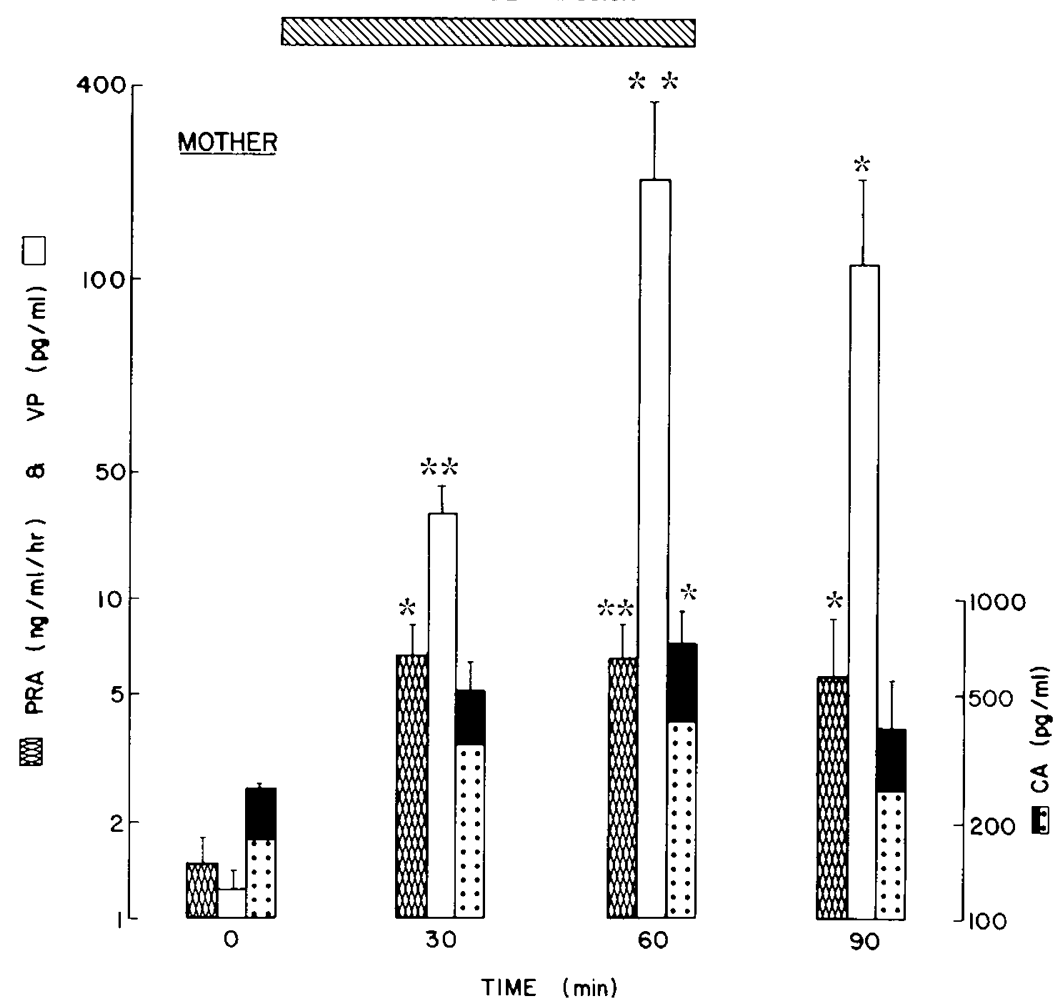

Fig. 2. Bar graph demonstrating changes in vasoactive mediators before, during, and after maternal hypotension: plasma renin activity (PRA, $\left.\mathrm{ng} \cdot \mathrm{ml}^{-1} \cdot \mathrm{h}^{-1}\right)$ (hatched bar), vasopressin $\left(V P, \mathrm{pg} \cdot \mathrm{ml}^{-1}\right)$ (open bar), catecholamines $\left(C A, \mathrm{pg} \cdot \mathrm{ml}^{-1}\right)$ (composed of solid upper portion, epinephrine, and stippled lower portion, norepinephrine). The effects on the fetus, upper section of graph, and on the mother, lower section, are demonstrated. Data expressed as mean \pm SE. ${ }^{*} p<0.05,{ }^{* *} p<0.01$.

Table 1. Blood composition (mean $\pm S E$ ) before, during, and after nitroprusside infusion

\begin{tabular}{|c|c|c|c|c|c|c|}
\hline & \multicolumn{3}{|c|}{ Maternal hypotension } & \multicolumn{3}{|c|}{ Fetal hypotension } \\
\hline & Control & Hypotenion & Recovery & Control & Hypotension & Recovery \\
\hline \multicolumn{7}{|l|}{ Fetal values } \\
\hline $\mathrm{pH}$ & $7.336 \pm 0.013$ & $7.323 \pm 0.008$ & $7.333 \pm 0.012$ & $7.391 \pm 0.010$ & $7.364 \pm 0.014$ & $7.371 \pm 0.013$ \\
\hline $\mathrm{PO}_{2}$ (torr) & $25 \pm 0.7$ & $22 \pm 1.3$ & $25 \pm 0.8$ & $22 \pm 0.9$ & $23 \pm 0.8$ & $23 \pm 0.8$ \\
\hline $\mathrm{PCO}_{2}$ (torr) & $46 \pm 1.5$ & $46 \pm 1.8$ & $45 \pm 1.5$ & $43 \pm 1.1$ & $44 \pm 0.6$ & $43 \pm 0.8$ \\
\hline $\mathrm{Na}\left(\mathrm{mEq} \cdot \mathrm{1}^{-1}\right)$ & $143 \pm 2.0$ & $145 \pm 2.2$ & $144 \pm 1.6$ & $144 \pm 1.4$ & $143 \pm 1.3$ & $144 \pm 1.0$ \\
\hline Osmol $\left(\right.$ mosmol $\left.\cdot \mathrm{kg}^{-1}\right)$ & $297 \pm 4.7$ & $293 \pm 2.5$ & $302 \pm 5.6$ & $297 \pm 2.3$ & $300 \pm 1.4$ & $302 \pm 2.5$ \\
\hline \multicolumn{7}{|l|}{ Maternal values } \\
\hline $\mathrm{pH}$ & $7.444 \pm 0.012$ & $7.470 \pm 0.018$ & $7.434 \pm 0.008$ & & & \\
\hline $\mathrm{PO}_{2}$ (torr) & $107 \pm 2.0$ & $103 \pm 7.0$ & $104 \pm 2.6$ & & & \\
\hline $\mathrm{PCO}_{2}$ (torr) & $34 \pm 1.1$ & $31 \pm 1.8$ & $34 \pm 1.0$ & & & \\
\hline $\mathrm{Na}\left(\mathrm{mEq} \cdot 1^{-1}\right)$ & $146 \pm 1.2$ & $146 \pm 2.0$ & $145 \pm 2.0$ & & & \\
\hline Osmol $\left(\right.$ mosmol $\left.\cdot \mathrm{kg}^{-1}\right)$ & $300 \pm 3.3$ & $300 \pm 4.9$ & $309 \pm 5.6$ & & & \\
\hline
\end{tabular}



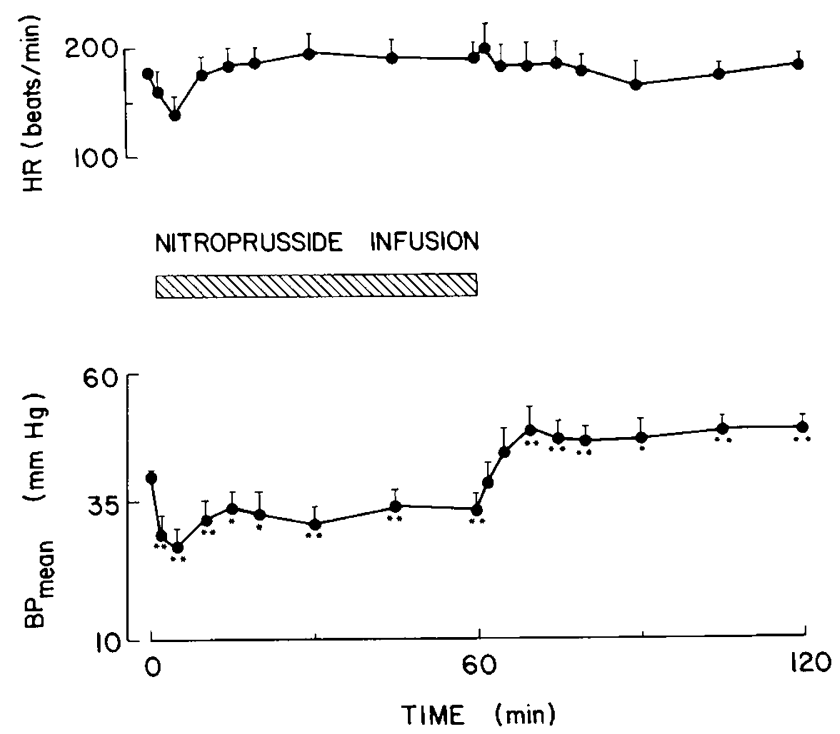

Fig. 3. Changes in heart rate (top) and mean blood pressure (bottom) before, during, and after fetal nitroprusside-induced hypotension (as indicated). Data expressed as mean $\pm \mathrm{SE}$. ${ }^{*} p<0.05,{ }^{* *} p<0.01$.

$4.3 \pm 3.4$ to $1054 \pm 772 \mathrm{pg} \cdot \mathrm{ml}^{-1}$ after $60 \mathrm{~min}$ of hypotension $(p$ $<0.0002$ ). Peak vasopressin concentration correlated significantly with the total nitroprusside dose $(r=0.87, p<0.01)$. Fetal plasma renin activity also increased from a control mean of $5.7 \pm 2.2$ to $22.2 \pm 7.1 \mathrm{ng} \cdot \mathrm{ml}^{-1} \cdot \mathrm{h}^{-1}(p<0.004)$ at $60 \mathrm{~min}$. Significant changes were also found for epinephrine $(p<0.04)$ and total catecholamine $(p<0.02)$. Plasma levels of vasopressin and renin activity were still elevated $30 \mathrm{~min}$ after the end of infusion.

There were no statistically significant changes in mean acidbase state or blood gas tensions in either the ewe or the fetus after infusion of nitroprusside in group B (Table 1). The mean control plasma sodium concentration $\left(145 \pm 1.5 \mathrm{mEq} \cdot 1^{-1}\right)$ and osmolality $\left(297 \pm 2.3 \mathrm{mosmol} \cdot \mathrm{kg}^{-1}\right)$ were within normal range for sheep and remained unchanged during the experiment. The hematocrit also remained unchanged (start $=32.7 \pm 1.5 \%$, end $=32.3 \pm 1.8 \%$ ).

\section{DISCUSSION}

The present experiments show that both the pregnant ewe and the fetal lamb respond to induced hypotension by increased release into the circulation of vasopressin and renin and to a lesser extent norepinephrine. In the fetus, there was also a prolonged rebound hypertension associated with persistent high levels of vasopressin and plasma renin activity. In addition, fetuses of mothers with induced hypotension also respond early (30 $\mathrm{min}$ ) with release of vasopressin followed by release of renin and norepinephrine by the end of the hypotensive period ( 60 $\min$ ).

The degree of maternal or fetal hypotension produced in our experiment did not cause significant changes in fetal or maternal oxygenation, acid base, osmolal, or sodium composition. It is therefore unlikely that the activation of vasoactive systems were due to hypoxemia or hemoconcentration.

Release of vasopressin may be stimulated by hypotension or hypovolemia $(2,3,12)$. In the present experiments hypotension was produced pharmacologically without directly altering blood volume; however, nitroprusside has been reported to produce intravascular volume depletion by sudden pooling of blood in dilated capacitance vessels (13). Therefore, it is possible that some of the hormonal responses we observed were secondary to hypovolemia as well as hypotension. The increase in and persistently elevated levels of plasma vasopressin that we observed in the fetus are similar to those observed by Ross et al. (14) except

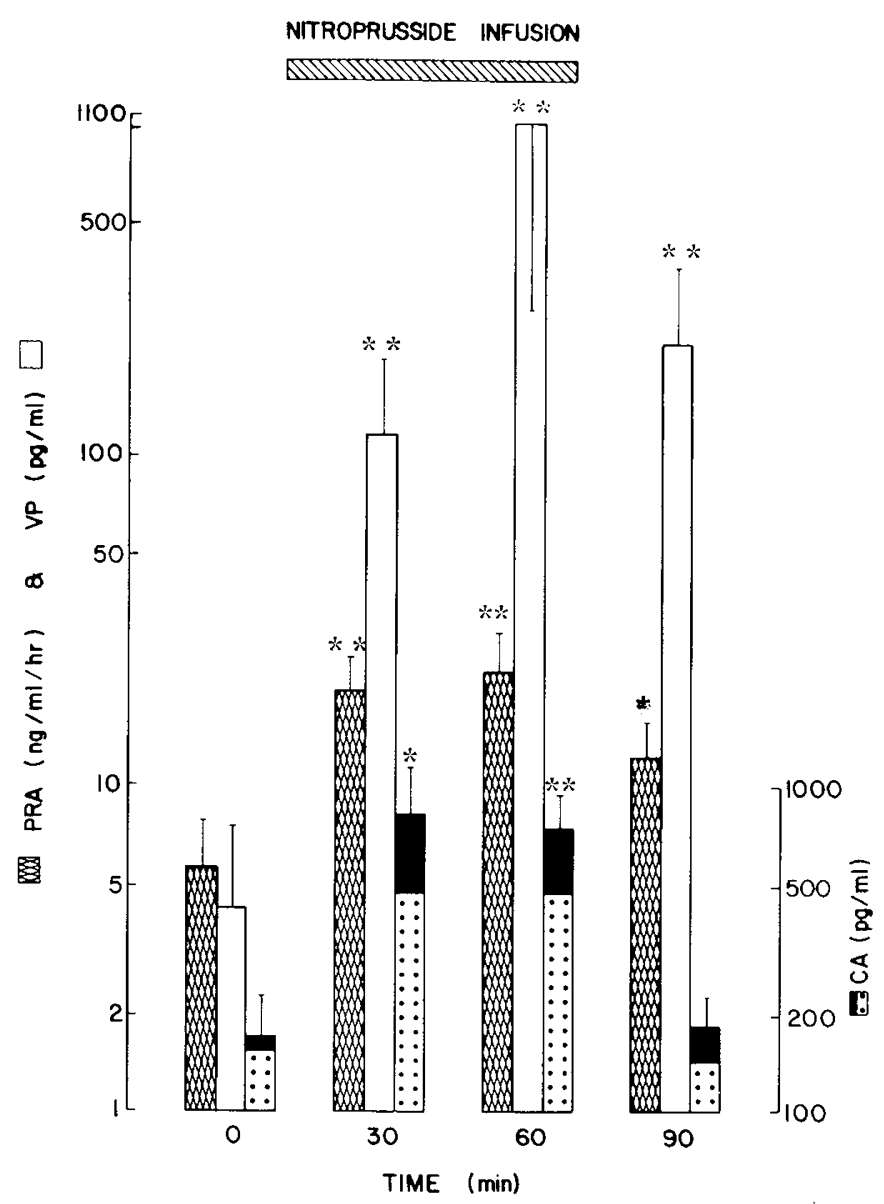

Fig. 4. Bar graph demonstrating changes in vasoactive mediators before, during, and after fetal hypotension: plasma renin activity ( $P R A$, $\left.\mathrm{ng} \cdot \mathrm{ml}^{-1} \cdot \mathrm{h}^{-1}\right)$ (hatched bar), vasopressin $\left(V P, \mathrm{pg} \cdot \mathrm{ml}^{-1}\right)$ (open bar), catecholamines $\left(C A, \mathrm{pg} \cdot \mathrm{ml}^{-1}\right)$ (composed of solid upper portion, epinephrine, and stippled lower portion, norepinephrine). Data expressed as mean \pm SE. ${ }^{*} p<0.05,{ }^{* *} p<0.01$.

that our peak levels of vasopressin and our nitroprusside infusion dose were higher. The difference in the protocol assay, or animal sensitivity and response to the nitroprusside infusion may be responsible for the varied findings. Inasmuch as there is a direct relationship between mean arterial blood pressure and levels of endogenous or exogenous vasopressin $(15,16)$, the vasopressin released by the mother or fetus during our experiments is most likely functioning as a vasopressor serving to support blood pressure. Perhaps vasopressin secretion is the cause of the tachyphylaxis to nitroprusside reported by others (17) and observed herein when two animals required a constantly increasing nitroprusside dose. Temporally, this increased dose requirement was associated with a marked increase in vasopressin concentration.

During a hypotensive stress to the fetal lamb or pregnant ewe, we observed significant increases in plasma renin activity. Pharmacologically induced hypotension also has been reported to stimulate renin and angiotensin release that act to support systemic blood pressure $(5-8,18)$ and uterine blood flow (19-23). Experiments on chronically cannulated fetal animals suggest strongly that a functional renin-angiotensin system is essential for normal fetal cardiovascular homeostasis $(20,24)$. Renin may be released during hypotension by direct neural mediation ( 5 , 25) and/or by reflex feedback mechanism whereby angiotensin stimulates catecholamine release $(26,27)$. Furthermore, the duration of renin activity may be increased because nitroprusside diminishes mesenteric blood flow (28) and therefore, presumably decreases hepatic renin metabolism (29). Our results on plasma renin activity after induced hypotension suggest that the renin- 
angiotensin system plays a significant role in both the pregnant ewe and fetal lamb to support the systemic and uterine circulations during pregnancy and fetal life.

The response of the sympathetic nervous system to hypotension is well described in adults. Broughton Pipkin et al. (20) report that this system is immature in the fetus and that other hormonal vasoactive systems are more important. The data presented herein suggest that despite this immaturity, the fetal sympathetic nervous system responds to hypotension.

When comparing maternal and fetal responses to nitroprusside-induced hypotension, in order to achieve the same percentage drop in blood pressure, the fetus required a higher dose of the drug than the pregnant ewe. Similarly, the fetus responded to the hypotensive stress with higher levels of all measured vasoactive mediators. These data might be interpreted as indicating a developmental change between the fetal and adult responses to an hypotensive stress. Because of the presence of vasoactive mediators, more nitroprusside is then needed to achieve the same degree of hypotension in the fetus compared with the pregnant ewe. Furthermore, when the hypotensive stress is removed in the fetus, there is a longer period of hypertension associated with elevated levels of vasoactive mediators. The results also may be explained by differences in the fetal and maternal vascular beds and their abilities to withstand hypotensive challenges.

Vasopressin, renin-angiotensin, and catecholamines show interactive effects with regard to secretion and homeostatic functions. Thus, despite greater responses seen with one vasoactive mediator over another, one cannot determine from our data what is the relative importance of each of the mediators in the defense of hypotension.

During maternal hypotension the stimulus for the rise in fetal vasopressin and plasma renin activity is likely to be uteroplacental hypoperfusion. High levels of vasopressin and components of the renin-angiotensin system would serve to maintain adequate fetal oxygen uptake (30). It is unlikely that the increase in vasopressin in fetal plasma is of maternal origin inasmuch as there is no evidence of its transfer across the sheep placenta (31). The rise in plasma renin activity in the mother and fetus during maternal hypotension may serve to maintain adequate placental blood flow either directly or indirectly by stimulation of prostaglandin $\mathrm{E}$ synthesis and by interaction with the sympathetic nervous system $(21,22,32)$.

The nonpregnant (8) and pregnant ewe's blood pressure returned to preinfusion levels shortly after the end of nitroprusside infusion. The fetus became and remained hypertensive for more than $1 \mathrm{~h}$ after the end of the infusion. This prolonged hypertension was associated with elevated levels of vasopressin and renin activity. We speculate this represents immaturity of the fetus to fine tune the regulation, release, or metabolism of vasoactive mediators. Ross et al. (14) suggested that sustained elevated vasopressin levels were not due to decreased renal vasopressin clearance. Another possibility to account for persistently elevated levels of vasoactive mediators may be a consequence of the vasodilator properties of nitroprusside. By vasodilating the arterial and venous beds, sodium nitroprusside causes a decreased left ventricular filling pressure. Inasmuch as the fetal heart is already working at close to the maximum stroke volume, cardiac output might suffer if hormonal mediators are not secreted to help support the blood pressure. Thus, the elevation in levels of vasoactive mediators may represent the body's continued need to support the cardiac output.

Sodium nitroprusside has been used clinically only sporadically during pregnancy (33). Cyanide toxicity is a concern when using this drug. The dose we used (excluding the two maternal animals requiring large infusions) was within the suggested pharmacologically safe range to minimize the possibilities of cyanide poisoning in humans (34). Furthermore, none of the animals developed a metabolic acidosis, a sign of cyanide poisoning. Because the peak plasma level of vasopressin correlates with the total nitroprusside concentration, we speculate that there is an interanimal variation in sensitivity to nitroprusside causing variable degrees of vascular vasodilation and variable falls in blood pressure that would then stimulate variable levels of vasopressin release to support the hypotension.

In summary, these experiments show that both the pregnant ewe and the fetus respond to induced hypotension by increased release of vasopressin, renin, and catecholamines. The correlation between peak vasopressin levels and total nitroprusside doses suggests that vasopressin is important in the maintenance of blood pressure in the fetus as well as the pregnant ewe and that the release of vasopressin may be proportional to the hypotensive challenge. However, the relative importance of the three systems studied remains to be examined. The release of vasopressin, renin-angiotensin, and norepinephrine by the fetus during maternal hypotension, despite a normal clinical status and normal arterial blood gas determinations, suggests that they are more sensitive indicators for fetal compromise than fetal heart rate or acid-base status. We speculate that the synergism between vasopressin and renin released by the pregnant ewe and the fetus during hypotension serve to maintain adequate uterine and placental blood flows. Finally, the persistent hypertension in the fetus after the end of nitroprusside infusion, may represent immaturity of the fetus' ability to precisely regulate, release, or metabolize vasoactive mediators.

\section{REFERENCES}

1. Paul RH 1980 Fetal Distress. In: Quilligan EJ, Kretchner N (eds) Fetal and Maternal Medicine. Wiley Medical Publication, New York, pp 317-332

2. Robillard JE, Weitzman RE, Fisher DA, Smith FG 1979 The dynamics of vasopressin release and blood volume regulation during fetal hemorrhage in the lamb fetus. Pediatr Res 13:606-610

3. Drummond WH, Rudolph AM, Keil LC, Gluckman PD, MacDonald AA, Heymann MA 1980 Arginine vasopressin and prolactin after hemorrhage in the fetal lamb. Am J Physiol 238:E214-E219

4. Rocha e Silva M Jr, Celso de Lima W, Castro de Souza Em 1978 Vasopressin secretion in response to haemorrhage: mathematical modeling of the factors involved. Pfleugers Arch 376:185-190

5. Abukhres MM, Ertel RJ, Dixit BN, Volmer RR 1979 Role of renin-angiotensin system in the blood pressure rebound to sodium nitroprusside in the conscious rat. Eur J Pharmacol 58:247-254

6. Pettinger WA, Campbell WB, Keeton K 1973 Adrenergic component of renin release induced by vasodilating antihypertensive drugs in the rat. Circ Res 33:82-86

7. Miller ED Jr, Ackerly AJ, Vaughan ED Jr, Peach MJ, Epstein RM 1977 The renin angiotensin system during controlled hypotension with sodium nitroprusside. Anesthesiology 47:257-262

8. Zubrow AB, Daniel SS, Stark RI, Husain MK, James LS 1983 Plasma renin, catecholamines, and vasopressin during nitroprusside-induced hypotension in ewes. Anesthesiology 58:245-249

9. Daniel SS, Stark RI, Husain MK, Baxi LV, James LS 1982 Role of vasopressin in fetal homeostasis. Am J Physiol 242:F740-F744

10. Stark RI, Daniel SS, Husain MK, Sanocka UM, Zubrow AB, James LS 1984 Vasopressin concentration in amniotic fluid as an index of fetal hypoxia: Mechanism of release in sheep. Pediatr Res 18:552-558

11. Husain MK, Fernando N, Shapiro M, Kagan A, Glick SM 1973 Radioimmunoassay of arginine vasopressin in human plasma. J Clin Endocrinol Metab 37:616-625

12. Share L 1962 Vascular volume and blood level of antidiuretic hormone. Am J Physiol 202:791-794

13. Schlant RC, Tsagaris TR, Robertson RJ Jr 1962 Studies on the acute cardiovascular effects of intravenous sodium nitroprusside. Am J Cardiol 9:51-59

14. Ross MG, Ervin MG, Leake RD, Habeeb O, Fisher PA 1986 Isovolemic hypotension in ovine fetus; plasma arginine vasopressin response and urinary effects. Am J Physiol 250:E564-E569

15. Robertson GL 1977 The regulation of vasopressin function in health and disease. Recent Prog Horm Res 33:333-385

16. Rurak DW 1978 Plasma vasopressin levels during hypoxaemia and the cardiovascular effects of exogenous vasopressin in foetal and adult sheep. J Physiol (Lond) 277:341-357

17. Posner MA, Rodkey FL, Tobey RE 1976 Nitroprusside-induced cyanide poisoning: antidotal effect of hydroxocobalamin. Anesthesiology 44:330335

18. Khambatta HJ, Stone JG, Khan E 1979 Hypertension during anesthesia on discontinuation of sodium nitroprusside-induced hypotension. Anesthesiology 51:127-130

19. Albertini R, Seino M, Scicli AG, Carretero OA 1980 Utero-placental renin in regulation of blood pressure in the pregnant rabbit. Am J Physiol 239:H266$\mathrm{H} 271$

20. Broughton Pipkin F 1982 The renin-angiotensin system in pregnancy: why bother? Br J Obstet Gynaecol 89:591-593 
21. Schirar A, Capponi A, Catt KJ 1980 Elevation of uterine angiotensin II receptors during early pregnancy in the rat. Endocrinology 106:1521-1527

22. Speroff L 1975 An autoregulatory role for prostaglandins in placental hemodynamics: their possible influence on blood pressure in pregnancy. $\mathrm{J}$ Reprod Med 15:181-188

23. Skinner SL, Lumbers ER, Symonds EM 1968 Renin concentration in human fetal and maternal tissues. Am J Obstet Gynecol 101:529-533

24. Iwamoto HS, Rudolph AM 1979 Effects of endogenous angiotensin II: role of renin-angiotensin II on the fetal circulation. J Dev Physiol 1:283-293

25. Hokfelt B 1978 Sympathetic amines, renin, and blood pressure. Acta Endocrinol [Suppl 216] (Copenh) 88:67-74

26. Peach MJ 1977 Renin-angiotensin system: biochemistry and mechanism of action. Physiol Rev 57:313-370

27. Pettinger WA 1978 Anesthetics and the renin-angiotensin-aldosterone axis. Anesthesiology 48:393-396

28. Wang HH, Lui LMP, Katz RL. 1977 A comparison of the cardiovascular effects of sodium nitroprusside and trimethaphan. Anesthesiology 46:40-48

29. Douglas WW 1980 Polypeptides-angiotensin plasma kinins and others. In:
Gilman AG, Goodman LS, Gilman A (eds) The Pharmacological Basis of Therapeutics. Maxmillan, New York, pp 647-667

30. Iwamoto HS, Rudolph AM, Keil LC, Heyman MA 1979 Hemodynamic responses of the sheep fetus to vasopressin infusion. Circ Res 44:430-436

31. Alexander DP, Britton HG, Forsling ML, Nixon DA, Ratcliffe JG 1974 Pituitary and plasma concentrations of adrenocorticotrophin, growth hormone, vasopressin, and oxytocin in fetal and maternal sheep during the latter half of gestation and the response to haemorrhage. Biol Neonate 24:206-219

32. Ferris TF, Stein JH, Kauffman J 1972 Uterine blood flow and uterine renin secretion. J Clin Invest 51:2827-2833

33. Stempel JE, O'Grady JP, Morton MJ, Johnson KA 1982 Use of sodium nitroprusside in complications of gestational hypertension. Obstet Gynecol 60:533-538

34. Rudd P, Blaschke TF 1985 Antihypertensive agents and the drug therapy of hypertension. In: Gilman AG, Goodman LS, Rall TW, Murad F (eds) The Pharmacological Basis of Therapeutics. Maxmillan, New York, pp 784-805 